Phenomenology \& Practice, Volume 2 (2008), No. 1, pp. 24 - 48.

\title{
Seeking Pedagogical Places
}

\author{
Andrew Foran, St. Francis Xavier University, Canada \\ Email: aforan@stfx.ca \\ Margaret Olson, St. Francis Xavier University, Canada \\ Email: molson@stfx.ca
}

\section{Abstract}

In this paper, we explore the meaning of pedagogical place by focusing on significant relations between teachers, students, and the various places in which they appear to find pedagogical thoughtfulness. By opening up educational discourse to consider pedagogy beyond established notions of classroom practice, we invite readers to step outside perceived limits of classroom instruction. How might we know a pedagogical moment when we encounter one? When does a place become pedagogical? Formerly an outdoor educator of youth and an elementary teacher, now university teacher educators, we explore what it means to be in the right place, pedagogically. Some observations on pedagogical place that emerged after reflecting on the lived experiences of various teachers include: different places are appropriate for engaging in different kinds of pedagogical activities with students; activities can be experienced as in place or out-ofplace; dwelling pedagogically is being absorbed, being able to dwell authentically in a learning experience without interruption or distraction; nature involves such areas as the natural ability and interests of the child, the relationship of the natural physical and social world, and the nature of learning.

\section{Seeking Pedagogical Places}

I realized pretty quick that you can't just beam your class outside, papers and all, expecting to do a more refreshing outdoor version of regular class. It's like tearing the roof and walls off the building and hoping the kids won't notice. Instead, I have to dream up missions-let's go collect some swampy water samples and bring them back inside where there are microscopes and desks, or let's go measure the angle of inclination to the top of the flagpole or the radio tower $5 \mathrm{~km}$ away, then come back inside and draw up

Copyright 2008. The authors, Andrew Foran and Margaret Olson, assign to Phenomenology \& Practice the right of first publication and educational and non-profit institutions a non-exclusive license to use this document for personal use and in courses of instruction provided that the article is used in full and this copyright statement is reproduced. Any other usage is prohibited without the express permission of the authors. 
a trig problem about it on the board. The outdoors is a rich source of experience, but as far as regular school subjects go, teaching often seems easier inside. (Leslie, Geography teacher)

Leslie draws our awareness to the point that place matters, pedagogically, as she distinguishes appropriate places for engaging in different kinds of pedagogical activities with students, and that activities can be experienced as in-place or out-of-place. She reminds us that we cannot just replace one place or thing for or with another "hoping the kids won't notice" and that swampy water, flagpoles, and radio towers belong outdoors; microscopes, desks, and "the board” belong indoors. We are now both university teacher educators, but one of us (Andrew Foran) is a former outdoor educator of youth, mostly outdoors, and one of us (Margaret Olson) is a former kindergarten, elementary teacher, mostly indoors. Both of us are also curious about what underlies Leslie's and others' ability to seek appropriate pedagogical places as well as how they know when they have found one. What does it mean to be in the right place, pedagogically? What occurs in lived time, lived body, lived space, and lived relationships when the place becomes pedagogical? What tensions arise for students and teachers when it does not?

In this article, we explore the meaning of pedagogical place by focusing on the significance of relations between teachers, students, and the various places in which they appear to find pedagogical thoughtfulness. By pedagogy we refer to the relationship between teachers and students in a place that binds the adult and the child educatively. We are not discussing pedagogy as a science or technical craft, nor as an art in teaching. Our emphasis, instead, is on how a teacher “sees" (van Manen, 2002, p. 23) children during the teaching experience. We have noticed that this kind of seeing occurs in multiple locations. While the inside experience, especially the classroom, appears to be the dominant place set aside for pedagogy in schools worldwide, there are teachers, students, and curricular moments that have garnered pedagogical meanings by engendering and embracing relational moments removed from entrenched notions of classroom practice. The focus here is to question the pedagogical relationship between people and place-we do not see pedagogy being simply one or the other-so we ask, then, what it means to dwell pedagogically in a place. To bring this phenomenon into focus we were open to many possible pedagogical experiences conducted outside the typical classroom location. For instance, Leslie describes dwelling pedagogically as being absorbed, as being able to dwell authentically in a learning experience without interruption or the distractions often present within a classroom:

The outside place for teaching can absorb you completely. Once I am out there I am lost to the world and my students as if these two items are reduced to the lowest common denominator: children and learning. I remember teaching a unit on soils. We spent our time making little individual piles of sand. There we were looming and screening under a blazing sun, oblivious to the goings on around us. I couldn't believe it when the kids were telling me that we had to go. I still do not know what happened to the allotted ninety minutes. I lost all track of the time, and from where we were I couldn't hear the bell. I loved it! No annoying reminders, interruptions, no schedule and no bells! Just me, my class, and piles of sifted soils, piles of glacial sand, the till of the past. We had time. (Leslie, Geography teacher) 
The relationship between the students and Leslie was pedagogically focused as they became absorbed and drawn into the learning experience this place offered. How might teachers open themselves more expansively to pedagogical possibilities with children by becoming more aware of their presupposed institutional confinements and moving into dwelling pedagogically both inside and outside of schools?

By opening up educational discourse to consider pedagogy beyond established notions of classroom practice, we invite readers to step outside perceived limits of classroom instruction. By considering other places where learning can occur we are creating an inquiry space that opens us to pedagogical possibilities. Where else might pedagogical moments occur? How might we know a pedagogical moment when we encounter one outside the classroom? When does a place become pedagogical?

\section{Methodological Background}

A phenomenological lens enables us to address the numerous questions we have posed regarding what it means to dwell pedagogically in a place. Our intention is to explore teachers' lived experience (van Manen, 1997), the concrete moment, of the teacher engaging children in learning. Our purpose is to move beyond theories, strategies, and debates that confront teachers daily. Orientating our practices pedagogically and our research phenomenologically allows us to challenge entrenched, taken-for-granted conceptions of formal education. Our phenomenological methodology aims to make connections with a "practical pedagogical orientation" (van Manen, 1988, p. 411) to the relational encounter through an examination of lived experiences and the showing of these experiences (Sokolowski, 2000) through a textual (re)presentation of the lived experience (van Manen, 1997).

Phenomenology provides descriptions of lived experiences and hermeneutics reveals an understanding of the moment through interpretation. This methodology can be harnessed to articulate the poignant insights of teachers' experiential pedagogical moments that enable the taken-for-granted-ness of teaching to eventually become visible and interpretable. Through layers of hermeneutic reflection, pre-understandings can disturb and break through the insulating surface of taken-for-granted assumptions that have been built up over time. Our hope is to reawaken teachers pedagogically to the world by showing the experience of teaching in places other than classrooms. By actively reflecting on pedagogical encounters, we can learn about the richness of pedagogy and the taken-for-granted-ness of teaching.

Merleau-Ponty (1962) presents the complexity and simplicity of the phenomenological method as "a matter of describing, not of explaining or analyzing” (p. viii). Phenomenology is a process that brackets an experience (Husserl, 1989), and by the unique approach of the researcher, uses descriptive text and language to craft the lived experience. Influences that need bracketing, and that are of direct importance to this article, include a quagmire of theories of learning and ideas about teaching as a pedagogical act. In using the phenomenological method, we focus on what was present or absent in the teachers' pedagogical experiences. Dahlberg, Drew, and Nyström (2002) suggest that bracketing theoretical assumptions or pre-understandings 
in teaching methodology allows us to show, rather than argue about, the pedagogical experience of teachers. We can see the uniqueness of the experience, which allows for a more open investigation that remains true to the phenomena of pedagogical place. The vital experience here is the phenomena of the teacher engaged in pedagogical encounters with children as a lived experience.

\section{Lived Experiences: Lifeworld Data}

Phenomenology, philosophically rooted in the affirmation of human lived experiences, draws on concrete experiences, but also relies on a range of artistic, imaginary, and descriptive texts to show us the moment, the "phenomenological now" (Moran, 2001, p. 43). By using descriptive sources in the form of anecdotes, we resist the abstraction of philosophy, scientific empiricism, and argued explanation.

The crafting of anecdotes, written by teachers through reflective conversations, provides the data to support our inquiry. The anecdote is a portrayal of a concrete lived experience; it attempts to guard against "abstract theoretical thought" (van Manen, 1997, p. 119). Through these anecdotes we present the "here and now" (see Merleau-Ponty, 1962) of pedagogical moments in places outside the classroom. The use of anecdotes, within the phenomenological method, is not intended to validate science, prove theories, or establish factual-empirical quantification (van Manen,1997); rather, it is essential in conducting reflective lifeworld research (Dahlberg, Drew, \& Nyström, 2002). Each anecdotal description is based on actual experiences and not only provides an intimate link to past moments, but also, with hermeneutical reflection, provides elements needed to inform pedagogical practices.

We focus on the lived experiences of teachers who seek pedagogical understanding in places where relational encounters occur within their practice. These teachers shared their livedexperience descriptions by crafting an anecdote that captures a specific pedagogical moment they experienced teaching outside the classroom. Through open-ended phenomenologicalhermeneutic conversations with selected educators (and each other), pedagogical insights involving pedagogical place emerged. The anecdotes for this paper were gathered from two sources: (1) open-ended phenomenological-hermeneutic conversations with teachers practicing in Nova Scotian schools, part of Foran's (2006) doctoral study; and (2) lived experience descriptions from Olson's recollections of her own experience as a Canadian elementary teacher and teacher educator.

The anecdotes in this article represent a careful blend of teacher reflections, researcher reflections, and significant literary sources. The result is a text of theory and practice: a lived praxis (see Smits, 1997) for teacher education. The research, therefore, is presented as reflective anecdotes grounded in their situated contexts.

\section{Seeking the Meaning of Pedagogical Places}

Classrooms are often taken for granted as "natural” places for pedagogy to occur. That is their 
purpose. Mere mention of the word school is often enough to conjure nostalgic recollections among adults, drawing them back into memories of places they occupied as learners. The spectrum of words used to describe school experiences is vast, rich, and fraught with personal fears and delights. School stories tend to be associated with certain teachers, particular classrooms, personal hideouts, the gym, the office, hallways, lockers, the cafeteria, the playground, the back field, and even patches of woods where used for play during recess. These places evoke individual memories about school life, pedagogical moments not limited to classrooms. Yet such memories also describe ways in which people have felt bound, perhaps even coerced or frustrated by the intent of school. Schools, like other buildings, "are spatially about social knowledge- that is taken-for-granted-knowledge...Social knowledge is about the unconscious organizing principles for the description of society. Often a building is a concretization of these principles" (Hillier \& Hanson, 1984, p. 183). Teachers and children, then, not only bring their varying intentions for learning to school, but also are aware of the nonpedagogical intentions, or purpose of this place. At times, students and teachers intentions coincide with taken-for-granted intentions of school and of each other; at times they do not. We believe that examining places where pedagogical moments are experienced and where they are not can help us uncover lost dimensions of pedagogical place. We have realized that the meanings that emerge from dwelling with children in a place have been covered over by artificially imposed presuppositions that for many have taken on dimensions of permanence as rigid as the buildings we have learned to associate with school itself. In our work and in this article, we hope to illuminate some of the qualities of pedagogical places both inside and outside of school.

\section{When is a Classroom Not a Classroom?}

Hallways are taken-for-granted places where school members congregate daily as part of a scheduled routine on their way to learning sites—-the classrooms (see Figure 1).

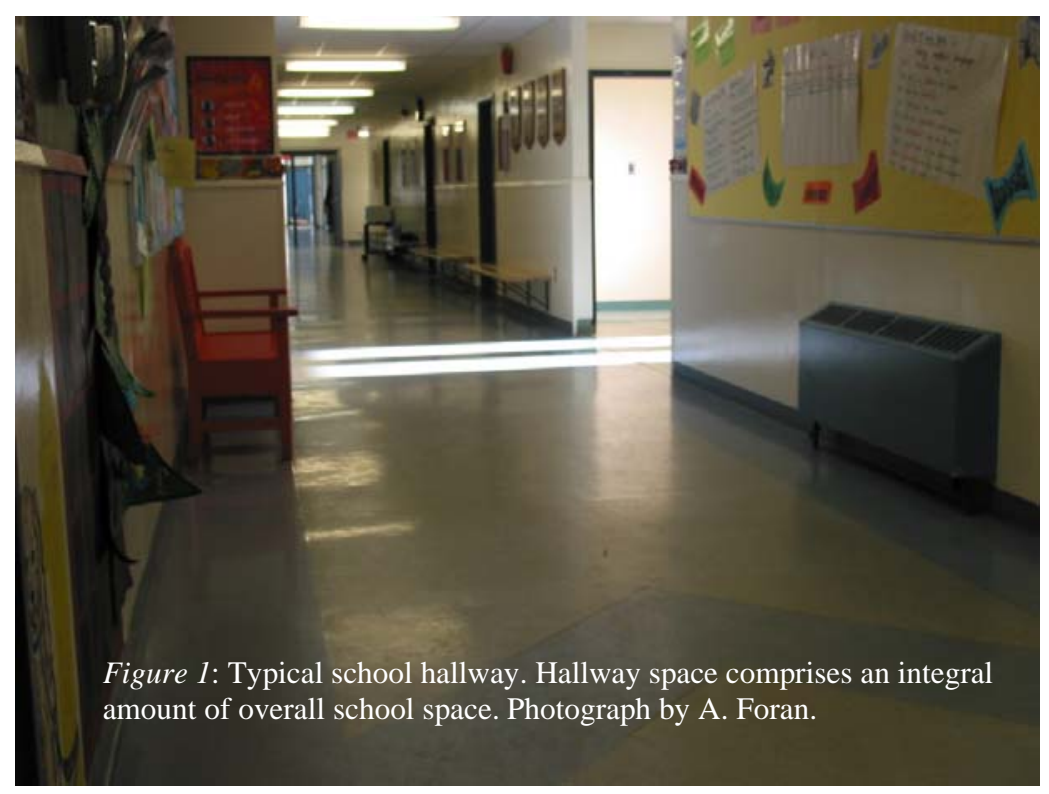


These passageways lead teachers and students into or out of school. The atmosphere of the hallway speaks volumes. By walking the school hallway, one is swept into the arterial flow, the rhythm and pulse of the place. Each step takes one deeper into the heart of the school, and with each echo of the treading foot one can sense the spirit of place. It is within the hallway that the intent of the place, the school, can be felt, even before entering the classrooms. Yet hallways have come to be thought of as non-pedagogical places not intended for instructional endeavors. What happens for teachers and students when learning and teaching occurs in this in-between place? What draws their attention? What is placed in tension?

\section{Shoes}

I had dismissed my kindergarten students and, once everyone was out of the classroom, coats not needed on this warm Spring day, I headed down the hall to the doorway to ensure all the children had managed to put on their outside shoes and had made it safely outside for the 15 minute recess. I fully expected to find one or two students needing assistance with the complex task of putting on and tying or buckling their shoes. As I watched the crowd of children from several classrooms dissipate, I noticed Liza and Brianne, two of my students, seated facing each other in the hallway, heads and bodies intently focused on the task at hand. As I started to approach them, Liza's voice stopped me in my tracks. "You need to poosh, poosh hard ... Harder ... That's it ... You are doing it ... Keep trying ... You just need to keep doing it ... Keep pooshing ... Good girl ... You are doing it ... Just keep pooshing ... I know it is very very hard ... You almost got it ... There! It's on! Good girl! You did it! Now do the next one. I will watch you ... You need to do it yourself." I could not interrupt this concerted effort but stood mesmerized by the process I had so fortuitously stumbled upon. "You got them both on all by yourself! See! You could do it yourself! Now you need to do the buckles. They are very hard. Your shoes are pretty. I like buckles, but they are very hard." Here a brief interlude while these two small girls took a moment to discuss the pleasures and difficulties of feminine dress. After this brief respite, Liza continued, “Just take your time ... Ok ... poot the strap in that hole ... Right there ... Ok, now pool it back ... Pool it back really hard ...Really really hard ... Yes, you can do it ... Just keep pooling ... Now poot that in the little hole ... Good girl ... You are doing it ... You are almost finished ... Keep going ... It's in! You did it ... Now just poosh that part in there. Yes, you can do it... You need to keep trying... You can do it when you try... Just keep trying... See! You did it again. You did it all! You did it all by yourself!!!!” Up they jumped and off they ran out the door. (Olson, kindergarten teacher)

What had I just witnessed? Why did I choose to stay and watch when they certainly did not need me and I could have been thankful that I would have time to go to the staffroom for a cup of coffee rather than spend it yet again on the floor with more shoes? I was fascinated by how Liza, 
a student who had come to us from Poland the previous September, speaking no English, was giving such clear, specific, verbal instructions to Brianna, especially when it might have been so much easier to have said, "Let me do it for you." That would have taken much less effort on both Liza's and Brianna's parts. I was fascinated with the patience and perseverance they both demonstrated in what I saw as a pedagogical moment. A moment as profound as any that I have experienced in the classroom. Yet what strikes me is how significant this moment was for learning, removed from the lessons just beyond the wall separating the classroom from the hallway. If teaching is about learning and pedagogy is about the relational bond between teacher and learner what occurred in that hallway before recess?

\section{Doubt}

I did not want to waste another minute inside. They followed me down the hallway laughing, scrambling; it was all so exciting. It was like they had never been outdoors before, or I, for that matter. When I reached the front door I froze. I could hear them behind me and I could see the brightness, the sun forcing its way through the little square opening. I started to laugh inside, but I know it was a nervous laugh. Then I came face to face with the door. My spontaneity took a turn. Just what was I doing? Would this work? Am I allowed to do this? I think I was afraid, of what, I do not know. I was flooded with "what if" questions. I almost turned around and said, "Back to the class! This is not right!" But I didn't. I pushed the release bar and went straight out. As I looked around I remember whispering a line from Dr. Seuss, "It's opener there in the wide open air." And then they came pouring out behind me. For some reason I had this shadow of doubt hanging over my head despite the brilliant afternoon. (Jay, Career and Life Management teacher)

What taken-for-granted assumptions about school and learning stopped Jay in his tracks? What did Jay experience at that moment of hesitation as he looked out from the inside of the doorway? His hands would have been touching, feeling the cool aluminum release bar common to school doors. We are curious to understand the cause of his hesitation. The hesitation may be rooted in the idea that a class occurring outside is somehow unnatural to conventional instruction. Pedagogically, we find Jay's anecdote disturbing because somewhere, deep within his lived experience there is a quiet realization that the classroom seems to have power over the pedagogical.

\section{Pedagogical Intent}

Schools "arouse...feelings alongside the associations” (Markus, 1993, p. 3). As previously noted, the mere mention of school immediately evokes meanings, memories, and stories about particular place experiences. What pedagogical implications are aroused when teachers abandon the accepted intentions expressed in the act of teaching indoors and embrace pedagogical 
possibilities in and of other places, and what happens to the relational associations of learning attached to the classroom in the physical sense?

From the two preceding anecdotes we can begin to tease out some pedagogical intentions. For Liza, perhaps because she was not yet old enough to have absorbed socially constructed conventions surrounding places in a school, the intensity she showed in teaching her friend was not disturbed by other conventions. Jay, however, was caught up short at the door as all of his pedagogical intentions were in tension with his presuppositions of what he should or could do in teaching his students. Liza's attention was drawn to Brianna's need to be able to get her shoes tied. The intention of going outside and the attention to the task of teaching Brianna how to tie her shoes in order to fulfill this intention were in harmony. They were, as Leslie introduced at the start of this paper, dwelling authentically in a learning experience without interruption or distraction. Jay's attention, originally focused on the anticipation of going outside with his students, was abruptly interrupted and refocused on the door, which became for him, a silent reminder that he was leaving the sanctity of the school. For a moment his pedagogical intentions were in tension with his socially constructed, taken-for-granted assumptions about place with regard to his pedagogical relationships with his students.

Being pedagogical determines that something is to be learned. Historically, scholars secluded themselves by stepping out of the on-going nature of the world. These scholars wanted quiet, concentration, and discipline as can still be found with the Carthusian order of monks captured in Gröning's (2006) film documentary, Into Great Silence. Schools are busy places where the intent is for children to be quiet and productive-on task, a curricular focus similar to that of the monks. Tuan (1977) states:

The building or architectural complex now stands as an environment capable of affecting the people who live in it...[this] space can refine human feeling and perception...Architectural space-even a simple hut surrounded by cleared ground - can define such sensations and render them vivid. Another influence is this: the built environment clarifies social roles and relations. People know better who they are and how they ought to behave when the arena is humanly designed rather than nature's raw stage. Finally, architecture "teaches"... In the absence of books and formal instruction, architecture is a key to comprehending reality. (p. 102)

The structure of the school itself has defined our roles as learners and teachers and the perception of where learning should take place. The building itself has the power to define (Markus, 1993). This causes us to wonder if classrooms may be at heart unnatural places for pedagogy to occurpresent-day classrooms classify, segregate, isolate and institutionalize children according to a controlling system. Classrooms are imposed onto children and teachers as the only place where learning occurs. A classroom conditions their behaviors, their thinking, their feeling, and their relationships with others. In schools much of the teacher's role is management-not pedagogy.

We often hear: "This is not the place for that." To question the sanctity of the classroom environment is to question the place of teaching. We contend that pedagogy should not be limited to a particular place; rather a quality relationship should exude an atmosphere and be felt in any place; in the classroom, a restaurant (see Olson \& Craig, in press) or outside (see Foran, 
2006). In another Christian example, Jesus taught anywhere and everywhere, as his Sermon on the Mount attests. Crowds gathered. No bell rang. Sound pedagogical practice does more than simply cover given material indoors or outdoors. As teachers, we need to develop our practice to include a variety of pedagogical places.

\section{Seeing Oneself as Pedagogically In or Out of Place}

People's connections to place are developed over time and are informed by their relational understandings of their personal associations to a physical place and to one another. We understand the relational as a metaphorical, metaphysical place, no less influential than the physicality of the school building that typically shelters the relational connection between teachers and students. Relph (1993) notes the following:

Belonging to a place, feeling part of it, gives many a positive sensation of security. Yet for others it may be oppressive and restrictive. Whether we know places with deep affection or merely as stopping points in our passage through the world, they are set apart in time and space because they have distinctive meanings for us. (p. 28)

This connection to place is of crucial importance to how a teacher is able to foster the relational capacity with students. Di Leo and Jacobs (2004) suggest the following:

the thisness of the classroom is always already uniquely defined through the interrelation of its place with a particular set of individuals ... as a site of interaction or struggle it is not generalizable ... It is a specific interaction between a place and individuals. (p. 3)

The following two anecdotes show pedagogical tensions when teachers felt out of place in the pedagogical relationships they believed they were expected to enact, bringing to consciousness deeply buried taken-for-granted assumptions of what they understood about their role and place as teachers.

\section{Supervising in the Hallway}

"I don't think I am cut out to be a very good teacher," Shelly confided in me after her first visit to her first practicum placement. "What do you mean?" I asked Shelly, surprised by her comment, given that I had found her to be an excellent student in my university class. "The children wouldn't listen to me," Shelly continued. "I felt like I had no control." "What happened?" I asked. Shelly explained that her placement was with a grade 4 teacher. Shelly had been very excited and nervous about what she might be expected to do, wanted to learn all she could, but also wanted to figure out her place in this teacher's classroom. The details came out. "The teacher wanted the students to do their recorder exam one at a time in the classroom with her and she wanted me to 
supervise the rest of the class in the hallway while they each waited for their turn to go in and be tested. It took a long time and I couldn't keep them all quiet. It was awful!"

I was stunned. I assured Shelly that this was in no way any indication of her potential to become a good teacher. As I attempted to find the words to reassure her, I began to articulate to her and to myself why this seemed to me to be such a bizarre situation. I talked about the possible stress students were likely feeling due to the recorder test that was occurring in the classroom. Of how impossible it would be for them to stand silently when one of the things they needed to do most was ask anyone coming out of the room, "How was it? How did you do?" for the benefit of the student who emerged as well as for themselves. I also began to think out loud of hallways and how they are a different kind of place than classrooms and how classroom behaviors are not hallway behaviors. I talked about how hallways in schools are places through which students are encouraged to move quickly as they go from one place to another. In this sense a hallway is not "really" a "place" at all. Standing still in one feels out of place.

Shelly seemed on one hand to be a bit reassured, but now also seemed to be more aware of what she did not know, a place she did not find a comfortable fit as she tried to imagine herself as a teacher. (Olson, University Professor)

Perhaps this example points toward the impossibility of achieving outside the classroom what is inherent within the classroom for as teachers we "regard buildings as material classifying devices; they organize people, things, and ideas in space so as to make conceptual systems concrete" (Markus, 1993, p. 19). As Shelly suggests, when engaging pedagogically with children outside of the classroom, the experience may put our teaching practices into question. A pedagogical encounter outside the classroom seemingly erodes a teacher's sense of place and as a result many feel a pull, a call to return to the familiarity of a place where student-teacher relationships are intact as intended by a school. A building is a space shared with others and we do not doubt its tangibility as a place. A building implies and holds power; it has "form, function and space [and] each has meanings in the field of social relations, each is capable of signifying who we are, to ourselves, in society and in the cosmic scheme of things" (Markus, p. 30). One challenge confronted by educators is to understand the importance and structure of social relations as an organizing power that equals that of the school building.

\section{Trespassing}

It's hard to put my finger on it. It's like I didn't belong. I wanted to be outside with them, but was this really the best place for us? I kept thinking, "Is this not better than being inside? Am I not making the curricular experience more real?" I know the kids were enjoying it. I was too. Sometimes I feel as if the classroom smothers us. I know I came alive outside, in some way. We were imagining that we were the first explorers pushing into the interior of a vast land that became Canada. I was reading the account from Pierre Gaultier de Varennes, sieur de La Vérendrye. I was watching the faces of my students as I was reading the passage. They were staring at the wood's path and the glint of shimmering water of the lake off to our left. If it weren't for their faces I would have 
left. I now wonder if this feeling of belonging was what the explorers from years ago felt. What I want to know is why I feel so displaced when I take them out here. These woods are on school property, but I always feel like a trespasser. (Jody, History teacher)

During the teaching moment outside the classroom, numerous pedagogical questions emerge: What are they learning? Are these experiences outside school beneficial to their development? Why was this lesson so different from others taught before? These are just a few examples of questions that might surface once outside the classroom. Another concern from Jody is the issue of the abundance of space once outside the classroom - a kind of pedagogical agoraphobia. Jody's concern is summarized in the observation of feeling disconnected from the students and teaching in an outside place. Again, outside teaching occurs with a class of students, in a nonroom, within an abundance of space. This becomes one of the challenges for teachers: to leave behind what is known, to venture into the unfamiliar, to hone a pedagogical practice that exists outside the norm of their established, pre-service training and their recollections of school as they experienced it. Regardless of Jody's uncertainty in an outside place, it was the relational encounter of pedagogy - the look on his students' faces - that held him in-place to explore the fullness of the pedagogical moment.

\section{Place Realization}

Outside the classroom, the teacher may be unsure of how to teach due to uncertainty about how to use the space. How does a teacher outside of the classroom, therefore, define a pedagogical practice? We find it interesting, almost puzzling, that a person can sense not belonging to a particular place that they normally inhabit. Shelly's developing image of her self as a teacher was brought into question when she found herself unable to "control" students, a role she implicitly understood as part of her responsibility as a teacher, one that appeared to preclude her pedagogical responsibilities. Jody, a more experienced teacher, seemed to have more pedagogical experience to draw upon as he attempted to make sense of how to relate with students in a place that seemed pedagogically unfamiliar, a space not naturally infused with pedagogical intent. Was Jody struggling to see this outside space as a pedagogical place? Did his sense of being a trespasser come from a presupposition that this outside space really was a place with its own particular meanings that were in tension with his pedagogical intent? Jody may have realized that indoor teacher intentions may not have belonged outside and that there was a need for a different way to be pedagogically present with his students.

What would cause a body-and in this particular instance, the teacher's body-to sense this displacement in a person's own world? Is the body the res extensa of the Cartesian definition of corpus? Therefore, it could be that for the teacher the bodily experience of leaving the inside world is a disturbance to the cogito. It could be possible for teachers, when stepping outside with their classes, to be "no longer concerned with [their] body, nor with time, nor with the world, as I experience them in ante-predicative knowledge, in the inner communion that I have with them" (Merleau-Ponty, 1962, p. 71).

As humans, the world is around us and inside us. We are part of the infinite world. Merleau- 
Ponty (1962) explains, "The world is not what I think, but what [I] live through. I am open to the world, I have no doubt that I am in communication with it, but I do not possess it; it is inexhaustible" (p. xvii). The teacher who is comfortable outside the school can provide important insights into the lived experience of the corporeal encounter with the outside world. Important comparisons in this pedagogical experience can be found between the teacher who is at home outdoors and the teacher who hesitated at the door, the teacher who sensed a gulf separating the inside world from the outside world and the teacher who experienced a sense of displacement.

Gendlin (1988) explains, "we are always situated...in the world, in a context, living in a certain way with others, trying to achieve..." (p. 44). Polanyi (1969) offers interpretations of experience in general terms and a description of how the body can be seen in relationship with every physical experience:

Our body is the only assembly of things known almost exclusively by relying on our awareness of them for attending to something else.... Every time we make sense of the world, we rely on our tacit knowledge of impacts made by the world on our body and the complex responses of our body to these impacts. (pp. 147-148)

This knowledge rests in making sense of the physical experience of being in the world. An important discovery would be the ability to distinguish the source of one's disassociation, displacement, and the feelings of not belonging. It is significant to note that Jody, in the end, remained outside and continued with the lesson of the early Canadian explorers, but he remained only as a trespasser.

To leave the classroom is to venture outside the bounds of what many teachers know to be familiar and consider inviolable about teaching. A teaching practice that can bridge these insideoutside worlds can allow for insight into what both worlds have to offer pedagogically. The following example (Olson \& Craig, in press) describes a teacher for whom the pedagogical relationship is not constrained by place:

You should have seen this white teacher interacting with this group of African American boys-his basketball team, you know-at Chili's Restaurant in Dallas. While waiting for their lunch, the teacher posed this really tough mathematics problem and set two boys up to solve it: one student assisted by the teacher; the other student aided by the rest of the basketball team. What was going on was so dynamic and productive and contrary to common stereotypes held about minority youth and white teachers... In fact, a crowd gathered around them...other teams as well as parents and some police officers having coffee as well.... All of us were stunned. All of this teaching and learning going on at Chili's? Can you believe it? My wife [a principal] and I [a principal] decided to sign our son up for his team. Both of us agreed that we would hire this teacher in a minute if he were employed in our school district.

Because this teacher dwells pedagogically with children, every place is filled with pedagogical possibilities - even a restaurant can offer learning opportunities. When asked later, the teacher/coach described in the above anecdote, told his version of the story this way: 
When I teach my class number sense and mental math strategies, it is exactly the same as when I take my basketball team out of town.... I will share the following with you as a way to explain my approach.... My basketball team was waiting for dinner. I pulled one student aside and showed him how to do a strategy in his head. Then, I involved the rest of the team-through one player-but I don't teach them the strategy [although they desperately want to learn it]. Pretty soon, you know, parents are drawn in, you know.... They see their children motivated by mathematics as well as by basketball, and all the time, they are supposed to be goofing off with their friends.

The coach/teacher continued:

And now we are in the middle of a restaurant, Chili's-I'll just use the example from Dallas two weeks ago. We're in the middle of Chili's and I've got one kid going up against another kid with the rest of the team involved.... Pretty soon, I have other basketball teams surrounding our table even though there is a game on television for them to watch.... But instead these kids (along with their parents who also have gathered) are glued to my teaching my students number sense. Next thing you know, four policemen are surrounding our table, curious, perhaps even suspicious, about what is going on.

Outside the classroom lessons offer experiences that reach farther than classroom walls by informing educators about other ways to relate pedagogically to children. Therefore, we are attuned to emerging similarities and contradictions between the inside and outside worlds. We further this inquiry by considering what occurs relationally because of place.

\section{Being-in-the-World}

Inside and outside are co-constitutional, each helping to define the other. Heidegger (1962) explains this intricate balance between seeking experiences (Erlebnisse) in the outside world, the intensification of experiences (Erfahrungen) on the inside through reflection, and the livingthrough of experiences (erleben) (pp. 71-72). The ancient Greeks frequently used an expression, ekstatikon, to describe the experience of a person "stepping-outside-self." This term is affiliated with "existence [, which]...viewed ontologically, is the original unity of being-outside-self that comes-toward-self, [and] comes-back-to-self” (Heidegger, 1982, p. 267). This common ancient expression is applicable to the lived experience of a teacher (and her or his students) stepping outside her or his lifeworld (Husserl, 1970), but going inward, pedagogically, to understand the experience. Arendt (1978) captures, for us, the pedagogical importance of experience outside the classroom. Arendt posits that being outside the school is to be really inside the world and the classroom inside the school is a place that is outside the world. The classroom world, she argues, represents an abstraction of the real world. Lindsay and Ewert (1999) echo this abstraction: 
Teaching in...schools focuse[s] on the facts as found in the textbooks and not... [on] applying knowledge...[;]textbooks are regarded as an efficient means of communicating information to students but, in reality, deny or restrict responsibility for learning as well as opportunities for active involvement in the learning process (p. 16).

When Olson was teaching kindergarten, she was asked by a greatly puzzled teaching colleague, "How can you teach them anything when they can't read?" Taking textbooks as the sole or primary authority and repository of accurate information, of course, has considerable consequences. The following example describes an exchange between a student and Olson, and offers an illustration of a taken-for-granted privilege of textbook knowledge above other ways of knowing:

I had taken my grade one class on a field trip to the farm. While there, I found myself in a heated debate with one of my students. I had pointed out a cow grazing close by. "That's not a cow," said the young boy assertively. "It's too big." I tried hard to change the boy's misconception, but he adamantly insisted that this could not be a cow because it was too big. When I asked him why he was so sure that this was not a cow, he replied. "I know what a cow looks like. I saw one in a book in our classroom. This is not a cow. It is too big." Realizing that I would make no progress here, I conceded the argument for the time being. Back in our classroom, I asked him to show me the book with the cow. Sure enough, he found it, saying "See. It's just little." There on the page was a picture of a pasture with a cow far in the background. The cow was indeed very small. Not having experienced cows, or possibly other animals, moving, the young boy had not taken perspective into account yet. Even at this young age, he was prepared to take the book as gospel over and above his own experience and anything I could tell him. It made me realize just how damaging books can be when they are seen as more authoritative than experience itself. (Olson, kindergarten teacher)

Arendt (1978) furthers understanding of pedagogical place by having teachers consider the following assertion: "Now school is by no means the world and must not pretend to be; it is an institution that we interpose between the private domain of home and the world in order to make the transition from the family to the world possible at all” (pp. 188-189).

Our concern is with when and where teaching is pedagogical-inside or outside! Arendt states that children grow into an "old world," gradually and the role for educators is to prepare them for their place in it (p. 177). Important here is for educators to preserve school as a transitional place. Arendt is clear when she states that teachers must know about the world and that their role is to "instruct others about it" (p. 189). In this context, the "function of the school is to teach children what the world is like and not to instruct them in the art of living” (p. 195). When does keeping children inside a classroom or taking them outside enable or disable the pedagogical relationship? This question is critical to ask because expectations are placed on children while they are in school. Teaching outside the classroom may very well be an attempt to bring students into closer contact with direct experience and thereby achieve a sound experiential pedagogy. This contact would seem to be contrary to more dominant methods and media of 
education delivery.

Inside and outside are dialectically related, dependent on one another for the experience of each, as this dialectic contributes to our sense of being in the world. The act of taking a class outside the building can create for teachers a unique inner-reflected experience that reveals the relational meaning of pedagogy. However, teachers may not be prepared pedagogically to undertake such a challenge. The potential lies in changing the notion of pedagogical place that can both compromise learning and enhance the educational experience of young people. Teaching outside is more than just covering a given subject outdoors; educators need to develop a pedagogical sense not only of the physical place but also of the relational place and what is pedagogically appropriate for particular students in particular places at particular times.

\section{Visiting Richard's House}

Richard's mother approached me excitedly to invite all Richard's kindergarten classmates and me as their teacher to their home for lunch. She explained that Richard had asked her if his friends could all come over for home cooked Chinese food. I assured her that she did not need to do that. "It would be a lot of work," I said. But she seemed as enthusiastic as Richard was and insisted that it would be a pleasure. She also wanted to teach the children how to make traditional Chinese egg rolls. She explained how she had thought about how to organize it so that each child would be able to make their own egg roll. I hesitantly agreed, feeling that she had no idea how much work she was creating for herself by inviting 27 five year olds to her home. She thanked me profusely, adding, "It won't be for a while. We are getting our basement refinished and when it is done the children can come."

The day finally arrived. Field trip permission slips had been signed and returned. I had gone over field trip rules with the children and we set off. We did not even need a bus! Richard proudly led the small parade headed off to his house with my teacher's aide Sharon and me bringing up the rear. On the way children pointed out places like "my house," "my friend's house," "the daycare," and "where we go to play." As we continued on our way the conversation subtly shifted from where children had been to where they were going. Some asked Richard questions about his house. Some began to talk of how they had "already been to Richard's house" and shared insider information. Neither Sharon nor I had previously been to Richard's house. My comment to students' questions was either: "I don't know. You will have to ask Richard." Or "We'll have to wait and see."

As the anticipation grew the little parade picked up momentum. A chant - "We're on our way to Richard's house" - began and soon spread though the group. Finally Richard stopped, pointed and exclaimed: "There it is!" Suddenly children broke rank and scurried helter skelter up to Richard's front door. Richard's mom threw the door open and enthusiastically welcomed them in. After futilely attempting to regain some control by telling the children to get back in line and basically being ignored by the

children and by Richard's mom, I too entered Richard's house as part of the bunch. The 
children were fine, Richard's mom was fine, Sharon was fine, and I was beside myself. I seemed to not know my place. This was not the way children entered our school as a class every day where they were expected to line up and wait for the bell to ring and be allowed in one-by-one.

We followed Richard's mom down stairs where, much to my relief, the children settled down, some more quickly than others! Sharon and I asked Richard's mom how we could help and soon everyone was arranged in groups in a very similar manner to what we would do together in our classroom with children busily engaged and adults assisting them in their learning. Some started eating while others went with Richard's mom to make their egg rolls and the groups rotated until everyone had made their own egg roll and eaten a variety of Chinese cuisine. Full and content, it was time to leave in order to get back to school at the time indicated on the field trip permission slips. Everyone thanked Richard and his mom for a very successful event. After trying to explain to some of the children why they could not just stay and play at Richard's house, we went on our way. (Olson, kindergarten teacher)

As teachers, our understanding of the term "outside the classroom," and our conception of teaching inside, often dictates our pedagogical practice. Yet, as the above anecdote exemplifies, the metaphorical, metaphysical, pedagogical relationship is as strong as any physical place in shaping pedagogical practice. We see similarities in the above anecdote in the story Jay told of being stopped at the door and wondering if he should or could go outside. While for Jay there appeared to be a distinct place where he seemed to believe his pedagogical relationship with students should occur, for Olson, this place seemed to stretch over space and time like a large rubber band until it reached the breaking point at Richard's front door. Olson had taken students on "field trips" many times to many different places and had not previously felt discomfort in taking students away from the school. How then was this particular field trip different? We look to the relational for clues. In this anecdote it was not so much the change in place as the change in relationship that occurred on Richard's front steps. For Olson, the pedagogical relationship had remained intact on other field trips, but in this case, Richard's mother was "at home" and Olson was not. This points to the pedagogical authority teachers are supposed to have, which was subsumed momentarily, under parental authority. Although teachers are legally supposed to behave in loco parentus, in this case, when a real parent appeared, the authority shifted and Olson needed to readjust. The children had no difficulty with this shift. As has been shown in the above example, what we think and believe on the inside influences our being in the world, the outside.

\section{The Experience of Roaming the Edge}

Crystal Cliffs is one of my favorite spots. It has the majesty of the trees of a typical Acadian forest. It has the wide-open fields, meadows that gradually rise to an exposed gypsum cliff. It has a little meandering river, a fresh water pond, a saltwater estuary, and the ocean. It offers everything needed for a biology-field trip designed to examine the 
insects that inhabit the edges of bordering habitats. To make the determination as to why certain species are present, the students collect bugs from various ecotones by pooting insects; sucking them up in a piece of rubber hose 4-5 inches long, with a piece of pantyhose tightly attached to one end that stops the insect. Then you can blow the bug into the collection jar. You have to go with the insects and I can't predict where or what will be along an edge at any given time. I have to be flexible allowing the kids to go between the zones. Students have to be able to roam, criss-crossing the ecotones; we were all over the place. It's hard at first, one would think it was teaching chaos, but it is not. There is a freedom in this lesson; we have to roam to learn. I still panic, at how disjointed the lesson appears, kids all over the place-the whole time I am feeling out-ofcontrol. But it always comes together, the data linked to the bigger context: historical, geographical, and geological of the area, and why certain insects gravitate in certain zones. Crystal Cliffs is a convergence of curriculum; so many subjects come into play helping us make sense. Could you imagine trying to pull this off indoors? Everything is so interconnected out here and that includes us as well! (Bobby, Biology teacher)

Schools can be awkward places, for they distinctly segregate students' being from the world, but their primary function is to prepare students for the world. The tension resides in how we as teachers prepare students through courses and how much of the real world we can use in this preparation. Bobby commented that when the teaching experience is extended to the outdoor world, there is no want; the outdoors offered all that was necessary for learning to occur. As Bobby stated emphatically on numerous occasions, "I had everything that I could ever want as a teacher when I went outdoors with my kids. All I have to do is roam and the outdoors will give me what I want!” The link with pedagogy is the experience of convergence: subject knowledge, student-insect finds, the roaming between ecotones, and a teacher guiding the learning experience that presents itself; not a controlling force artificially predetermining what learning should occur.

Bobby comments several times that other knowledge was allowed to exist within the lesson plan; it was much more than just insects. Subject separation or segregation is hard or next to impossible to maintain when teaching outdoors. As Bobby states:

How can I keep the world out of the lesson? When we are standing right in it, they see it, and I can't stop them from knowing it. As a teacher I am free to draw on what the outdoors offers at the time, and nature makes immediate sense for our learning. I cannot control everything out here. I have to go where the learning is best for my students.

This pedagogical freedom is not about Bobby breaking the teaching code, stepping outside the designated outcomes of the curriculum. Bobby allowed students to follow their learning interests and, pedagogically, gave them the freedom to roam the habitat edges to satisfy their inquiry. Pedagogically, we wonder if trust in the students is what allows Crystal Cliffs to stand out as a favorite learning place.

We see this as the simple connection that we, as humans, have to our world, which is primordial and existed before social conventions imposed their ways of being on our lives. The 
freedom for Bobby is in exploring, experiencing, and teaching his students without curricular restrictions; a manner of learning that existed long before schooling was institutionalizedlearning by freely roaming and naturally making links. Does Bobby's outside pedagogical experience of allowing students to roam freely allow, in turn, for a fuller convergence of learning possibilities because the natural connections result in having an abundance of resources for the class? Bobby's statement- “I have everything that I could want”-reminds us that, for good learning to occur, a teacher needs to support students in their learning. Important to the relationship, naturally, is trust. Does going outdoors free Bobby from acquiring the needed resources to develop appropriate learning experiences, or does it provide him with the freedom to trust students as they roam edges to learn?

Gadamer (2001) clarifies the epistemological understanding of freedom: "Freedom is not a fact in nature but rather... a fact of reason, something we must think, because without thinking of ourselves as free we cannot understand ourselves at all.” (p. 123). Gadamer (1986) asserts that freedom experienced as a conscious feeling is appropriate, because natural conditions allow for a being aware of choice and thus, able to act freely. An explanation for Bobby's sense of freedom in his teaching lies in the understanding that in the outdoors it makes perfect sense to open up a lesson to the many ways of knowing the world. Outside, Bobby could resist the artificial, overrationalized, mechanistic, subject separation that has come to dominate Western curricular offerings. Bobby was able to teach out from underneath the tutelage of the classroom and allow a pedagogical bond to develop naturally between the learning opportunities and the needs of the students.

As Bobby's students roam in and connect with their environment, Bobby is able to connect to people and place-“everything is interconnected”-trusting students relationally by allowing them to roam outside. Bobby is able to become that link between the natural world, the learning, and the confidence in the student-teacher relationship outside the school. When possible, students can roam freely, and the teacher can become more of a guide in the experience who helps them make connections to the curriculum. In establishing our classrooms we inadvertently structure our version of the world. Leaving this inner world could become difficult, and the simple act of stepping outside of a school to teach may not be possible for some teachers.

\section{Seeking Place and Pedagogy—A Relational Encounter}

We can now situate this article as an examination of the tension between the inner and outer worlds. We are sure that pedagogy is neither exclusive to, nor restricted to, an inside classroom practice. For Aoki (1990), the pedagogical relationship becomes an opportunity in which the "educator and the educated are allowed to dwell in a present that embraces past experiences and is open to possibilities yet to be” (p. 114). Burkholder (2003) refers to consilience as the ability to see something in its wholeness: not as an abstraction, but as the thing itself and connected to you directly. Similarly, Dewey (1902) also advocated that education should start with a child's interest in concrete, everyday experiences and build on that understanding to connect children with more formal subject matter. To ensure connections are made to the intended learning, and that the curriculum has relevance, each student participates in experiences drawn from 
community life and occupations. The curriculum is constructed around exploratory themes, and the student progresses through exploration and discovery (Dewey, 1902).

\section{Determinism or Indeterminism}

Every year I teach a unit on Entrepreneurialism, and I do a field trip to one of our localcommunity business. That year was the Moon Sugar Shack. I will never forget this little girl had soot all over her face. At the beginning of the winter term she was so awkward; concerned about her presence, how she looked, what she said, she was stuck and struggling to be her natural self. She worked hard just like all the other kids. Her job was to manage the sugar shack: simply keep the sap flow measured and the fires stoked for boiling. I remember seeing this girl, as we were packing up. She was different: she was not fussing with herself, she did not care, she was on a high, and she was in that zone. She was having an experience that was so rich for her that she was not concerned about her hair or how she looked. During the closing statements, she mentioned that she loved the fact that she knew she could run her own business: she liked math, she was organized, but she loved the hands on. For the first time she felt in control of what she could do, felt awake out here in the woods. She said that school smothered her. She wanted to run her own business and could care less what it was. I was floored. What a difference a day can make. She had long, straight, blond hair and she was covered in charcoal and she smelled of smoke from the sugar-shack fire. This young girl was just captured by her experience. She flourished in the freedom, outside the school. She was alive. Education is all about change, but I realized that I could not measure or evaluate that day for her. That was beyond my control. (Jay, Career and Life Management teacher)

Jay aligns himself with a notion of pedagogy: leading students to their learning and allowing them the space to experience it, first hand, with little teacher interference. This hands-off approach is difficult to maintain as a teacher: instinctively and as a result of their education, teachers want to involve themselves in their students' learning. The outdoors provides space that allows for a distancing to happen naturally between students and teachers. Jay explained that when he watches children play, even role-play, he is witness to freedom in self-expression. A child at play is the embodiment of non-restraint. The student Jay describes was playing a role of entrepreneur. Jay observed that the outside experience allowed this child to learn that her future could be undefined:

Why does everything have to be cast in stone with kids? It seems that when they come into high school there is a pressure to determine their futures as some forgone conclusion; undefined can be good when you're a kid. The indeterminate world is living the possible.

Similarly, Gadamer (1986) refers to a beauty that is recognizable in freedom. The freedom of play is not "some substitute dream-world" where we lose ourselves; rather, it is a "mirror...in which we catch a sight of ourselves in a way that is often unexpected or unfamiliar: what we are, 
what we might be, and what we are about” (p. 30). Play, even a role-play for school, is a powerful and creative experience for people of all ages. Pedagogically, the out-of-doors for Jay became a pedagogical place where learning did not need to be confined to a measured-andscored event that determines the future lives of students. The sugar shack showed a life that could be possible and that could not be determined by the conventions of scholastic performances. The teacher, away from the control of marking and evaluation, realized that not all learning could be measured.

Jay was also learning, or relearning, the pedagogical importance of freedom. Play is the power of spontaneous freedom. Play may very well be the human act that is without determinism. Jay's experience of freedom could very well be that of teaching the simple beauty of a role-play, and this witnessing of the educative change, by a teacher, would be liberating. The play here involved hands-on contact in the framework of the subject area-entrepreneurialismand it approached maturity when what it hinted at became a serious possibility: the indeterminate freedom of possibility.

\section{Freedom to Learn: Swinging and Singing, Inside Out}

My principal, Mr. White, introduced me to Jason, his mother Mrs. Jones, and brother Anthony with the explanation that the family would be moving to our area in a couple of months. Jason would be entering my grade one classroom and Mrs. Jones wanted to ensure that we were aware of Jason's special needs. Anthony was in grade four and doing well in school. Jason, on the other hand was, according to Mrs. Jones, "not like his brother." Mrs. Jones went on to explain that Jason did not enjoy books the way Anthony and their preschool brother did. He did not know his alphabet the way his preschool brother already did and was behind in skills that other children in his kindergarten class had acquired. Jason had been assessed during his kindergarten year and a recommendation for special services had been made. Mrs. Jones was now concerned that with their move, all of these plans might become derailed. Mr. White assured Mrs. Jones that we would take good care of Jason when he arrived but he would need to settle in to this new place before decisions could be made about any special services.

Two months later, Mrs. Jones arrived with Jason duly in tow. While his mother reminded me of how much difficulty Jason had in school, he looked down at the floor and said nothing. Mrs. Jones then left and Jason came with me into what was his new classroom. I knew that one of my jobs over the next few weeks would be to take careful note of Jason's progress so we could determine what, if any, special needs he might have. Jason was extremely quiet, never speaking unless spoken to and asked a specific question, which usually elicited at most a yes or no response. He sat very still in his desk, attempting to do what he was asked, but often responding with "I can't do that." Or "I don't know how." Jason did indeed appear to have very limited vocabulary and few if any reading, writing, or math skills. The more I watched and listened, the more it 
appeared that Jason was indeed out of place in this grade one classroom. We likely did need to have some reassessments made and special program services put in place.

About the time I had started to discuss my observations with Mr. White and arrange a meeting with Mrs. Jones, I was on regularly scheduled recess playground supervision. In the distance I happened to see a small boy on a swing going higher and higher. As I approached from behind to check on him and possibly suggest that he was likely going high enough now, I could see that it was Jason. I could also now hear him singing "The Alphabet Song" freely, fluently, and at the top of his lungs. I stopped, amazed. Could this be the same Jason who was so tentative, hesitant and quiet in the classroom? (Olson, kindergarten teacher)

We believe this is another example of freedom in action. Jason appeared to be experiencing a regularly scheduled daily recess not only as part of the imposed structure of schooling but also as a relief from the pressure he seemed to have learned would be a part of his time at school, a story he had been exposed to by his mother, likely at home and certainly in conversation with Olson. This story presupposed that Jason's introduction to schooling was to be fraught with difficulty and failure: school and Jason's natural ability would not be a good fit. It seemed as if Jason had absorbed this story of himself and was living it in the classroom space in ways that made his discomfort painfully apparent and confirmed the assumption that school was not the place for Jason. This taken-for-granted assumption had not included the playground. It was here that Jason was free to be himself, free to express his joy of learning without the pressure he had learned would be exerted on him to produce and perform in ways he already believed he was incapable of, free to behave naturally and be open to possibility. We believe that freedom to learn involves not only trust, but also faith in the child's natural ability and intuition to grow and develop, to move toward becoming a more mature, more educated individual. We also believe that it is incumbent upon teachers to ensure that students are able to feel this trust and faith and experience freedom to learn naturally in whatever physical places they find themselves together.

\section{Pedagogy of Place}

Teaching has evolved greatly from the days of informal gatherings, prior to public school buildings, when education was a parental responsibility, a tutoring arrangement, an apprenticeship, or a provision made to a select few by a religious authority. School has developed into a formal-institutional structure for educating children that is highly organized to include grade levels, outcomes to mark progression, established institutional modes of rational, subject-specific instruction, and credentialed teachers who are highly skilled and trained to work within school buildings. This evolution of educational development has tended to leave the outdoors outside the ways we teach our children. An important discovery from the shared anecdotes in this article is the existence of a phenomenological moment, when pedagogy is realized as a concrete experience between the teacher and students; it is a lived experience that supersedes the dominant indoor agenda. Places can become geographic centers in one's personal

and professional lives that are "carved out of chaotic space...[and] set apart from the rest of the 
world as a holy precinct” (Bollnow, 1961, p. 34). The importance a place can have in a person's being can border on spiritual sanctity, evoking ardent feelings that remind one of what is most precious. This is a full-body experience, the intentional awareness of being-in-the-world that encourages the body, beyond the desk, the classroom, or the school.

How can the conditions of pedagogy change as a result of location, given that the experience of teaching is still involved? Pedagogical distinctiveness draws from the power of the place where teaching evolves, and learning activities are associated with the lesson. Dovey (1985) identifies place as "the interaction between people and a physical setting together with a set of meanings" (p. 94). Pedagogically, inside or outside, belonging was associated with a student's place in the world. The "outside the classroom" teaching experience underscored a convergence of the fundamental connections of three things: place, memory, and human identity. Tuan (1977) makes this observation: "Undifferentiated space becomes place as we get to know it better and endow it with value" (p. 6). Teaching away from the dominance of the classroom space enables learning away from the shrill bell, crowded halls, booming announcements, stacks of marking, and the confines of an institution. Outside learning is free to get caught up in the power of doing - away from the desk, the text, and the chalkboard. For students and for the teacher outside the classroom, their excitement was the excitement of the unexplored and an uncharted way to experience learning.

After reflecting on the lived experiences of teachers outside the classroom, we have discovered that a few essential qualities of pedagogical place emerged: there are appropriate places for engaging in different kinds of pedagogical activities with students and that activities can be experienced as in place or out-of-place; dwelling pedagogically is being absorbed and being able to dwell authentically in a learning experience without interruption or distraction; nature is found in such areas as the natural ability and interests of the child, the relationship of the natural physical and social world, the nature of learning. Thus, because of place, pedagogy became something as understood for these teachers; they could see the significance of the relational qualities existing between teachers and students. Conversely, place became a shared experience between teachers and students and not just a geographical location that was walked over or through.

Pedagogy of place showed, that for these teachers, the place they were in became their world. The student in that place allowed the teacher to see the relational connection beyond contractual responsibility for a class list. The teachers experienced time not as a mechanistic division in the day, but as embodied and part of the learning process. Time was not something that governed them. Time was fluid between teaching and curriculum, students and learning, binding them to place. The pedagogical place allowed teachers to become attuned, not to the lesson as an abstraction, but to the student in a place as connected to a genuine process.

Tuan (1977) notes: "The designed environment serves an educational purpose. In some societies the building is the primary text for handing down a tradition, for presenting a view of reality” (p. 112). Clearly, then, place is important to pedagogy. Following Di Leo and Jacobs (2004) suggestion, research must begin to consider all places for teaching from the perspective of pedagogical theory (p. 10). Becker (2004) claims that being in a place allows a person to experience the world through the flesh. This is the educational move from the abstract to the tangible-from a concept to something palpable. Schooling is important in culturalization; 
assisting the social stability and continuation. The Industrial Revolution was the historical event that called the West indoors. As a people we turned away from one way of life to accept and embrace another way of existing that was disconnected from the natural world and this came to include learning from experience. Accordingly, we have come to accept a way of life that controlled our environment artificially. Gallagher (1993) states: "There are special things in the places all around us, but you may have to work hard to see them” (p. 23). Gallagher posits that the "interior worlds we create, from log cabins to airplane cabins, have climates that affect our well-being as surely as the climates outside” (p. 47). Considering Gallagher's insights, one should not take for granted indoor environments or outside places in how they could be impacting our relational capacity with children. And Gallagher posits: "When we enter 'behavior settings' - a school, restaurant, gas station, hospital — everything in that environment encourages us to maintain the status quo.” (p. 128). Thus stepping outside allows pedagogy to develop as a way of being between the teacher and students that falls outside the behavioral expectations of the institution. Pedagogy could be experienced as uniquely as the place where students and teachers find themselves.

What do teachers and students learn about their world, their learning, and themselves every time they enter their school building? The dominance of school buildings for pedagogy can explain our need for schools as a means of structuring the world, giving teachers control to bring order and focus for learning and teaching. When teachers go outside, the simple change in learning engagement may allow people to exit their own egocentrism and connect, through vulnerability to other people, the environment, and the here and now. Simply put, going outside can enable curious and adventurous teachers to seek places for their students to learn best; a pedagogical seeking of appropriate places for better learning opportunities to meet the needs of learners. School as place thus should not be considered lightly, from an architectural standpoint or from the naturalist call that connects students to nature. Clearly, the places we learn in influence more than just the curricular outcomes in that they shape who we are and how we relate to one another.

\section{References}

Aoki, T. (1990). Themes of teaching curriculum. In J. T. Sears \& J. D. Marshall (Eds.), Teaching and thinking about curriculum: Critical inquiries (pp. 111-114). New York: Teachers College Press.

Arendt, H. (1978). Between past and future: Eight exercises in political thought. New York: Penguin Books.

Becker, C. (2004). Pilgrimage to My Lai. In J. R. Di Leo \& W. R. Jacobs (Eds.), If classrooms matter: Progressive visions of educational environments (pp.115-131). New York: Routledge. 
Bollnow, O. F. (1961). Lived-space. Philosophy Today, 5, 31-40.

Burkholder, R. E. (2003). To see things in their wholeness: Consilience, natural history, and teaching literature outdoor. In H. Crimmel (Ed.), Teaching in the field: Working with students in the outdoor classroom (pp.17-32). Salt Lake City: The University of Utah Press.

Dahlberg, K., Drew, N. \& Nyström, M. (2002). Reflective lifeworld research. Lund, Sweden: Studentlitteratur.

Dewey, J. (1902). The child and the curriculum. Chicago: The University of Chicago Press.

Di Leo, J. R., \& Jacobs, W. R. (2004). If classrooms matter: Progressive visions of educational environments. New York: Routledge.

Dovey, K. (1985). An ecology of place and place making: Structures, processes, knots of meanings. In K. Dovey, P. Downton, \& G. Missingham (Eds.), Place and placemaking: Proceedings of the Paper 85 Conference (pp. 93-110). Melbourne, Australia.

Foran, A. (2006). Teaching outside the school: A phenomenological inquiry. Unpublished Doctorial Thesis. University of Alberta: Edmonton, Alberta.

Gadamer, H.-G. (2001). The beginning of knowledge. New York: Continuum.

Gadamer, H.-G. (1986). The relevance of the beautiful. Cambridge: Cambridge University Press.

Gallager, W. (1993). The power of place: How our surroundings shape our thoughts, and actions. New York: Harper Perennial.

Gendlin, E. T. (1988). Befindlichkeit: Heidegger and the philosophy and psychology. In K. Hoeller (Ed.), Heidegger and psychology. Review of Existential Psychology and Psychiatry, Special Issue, 43-71.

Gröning, P. (Director). (2006). Into great silence [Motion picture video]. Germany: Mongrel Media.

Heidegger, M. (1962). Being and time. New York: Harper \& Row.

Heidegger, M. (1982). The basic problems of phenomenology. Bloomington: Indiana University Press.

Hillier, B. \& Hanson, J. (1984). The social logic of space. Cambridge: Cambridge University Press. 
Husserl, E. (1970). The crises of European sciences and transcendental phenomenology. Evanston, IL: Northwestern University Press.

Husserl, E. (1989). Ideas pertaining to a pure phenomenology and to a phenomenological philosophy ( $2^{\text {nd }}$ book) [Rojcewicz, R. \& Schuwer, A., Trans.]. Dordrecht, The Netherlands: Kluwer Academic Publishers.

Lindsay, A. \& Ewert, A. (1999). Learning at the edge: Can experiential education contribute to educational reform? Journal of Experiential Education, 22(1), pp. 12-19.

Markus, T. (1993). Buildings and power: Freedom and control in the origin of modern building types. London: Routledge.

Merleau-Ponty, M. (1962). Phenomenology of perception. London: Routledge \& Kegan Paul.

Olson, M. \& Craig, C. (in press). "Small” stories and megnarratives: Accountability in balance. Teachers College Record, 111(2).

Moran, D. (2001). Introduction to phenomenology. New York: Routledge.

Polanyi, M. (1969). Knowing and being. Chicago, IL: University of Chicago Press.

Relph, E. (1993). Modernity and the reclamation of place. In D. Seamon (Ed.), Dwelling, seeing, and designing: Toward a phenomenological ecology. Albany, NY: State University of New York Press.

Smits, H. (1997). Hermeneutically-inspired action research: Living with the difficulties of understanding. Journal of Curriculum Theorizing, 13(1), 15-22.

Sokolowski, R. (2000). Introduction to phenomenology. New York: Cambridge University Press.

Tuan, Y.-F. (1977). Space and place: The perspective of experience. Minnesota, MN: University of Minnesota Press.

van Manen, M. (1988). The relation between research and pedagogy. In W. Pinar (Ed.), Contemporary curriculum discourses (pp. 437-452). Scottsdale: AZ:Gorsuch Scarisbride.

van Manen, M. (1997). Researching lived experience human science for an action sensitive pedagogy (2nd ed.). London, Ontario: Althouse Press.

van Manen, M. (2002). The tone of teaching. London, Ontario: Althouse Press. 
